Eastern Illinois University

The Keep

Faculty Research and Creative Activity

Early Childhood, Elementary \& Middle Level

Education

January 2015

\title{
Historical Thinking, Reading, and Writing about the World's Newest Nation, South Sudan
}

John H. Bickford III

Eastern Illinois University, jbickford@eiu.edu

Molly Sigler Bickford

Tolono Junior High School

Follow this and additional works at: http://thekeep.eiu.edu/eemedu_fac

Part of the Curriculum and Instruction Commons

\section{Recommended Citation}

Bickford, John H. III and Bickford, Molly Sigler, "Historical Thinking, Reading, and Writing about the World's Newest Nation, South Sudan" (2015). Faculty Research and Creative Activity. 43.

http://thekeep.eiu.edu/eemedu_fac/43

This Article is brought to you for free and open access by the Early Childhood, Elementary \& Middle Level Education at The Keep. It has been accepted for inclusion in Faculty Research and Creative Activity by an authorized administrator of The Keep. For more information, please contact tabruns@eiu.edu. 


\title{
Historical Thinking, Reading, and Writing about the World's Newest Nation, South Sudan
}

\author{
John H. Bickford III \\ Eastern Illinois University \\ Molly Sigler Bickford \\ Tolono Junior High School
}

State and national education initiatives have significantly increased expectations of students' non-fiction reading and writing. These initiatives provide the space for potential interdisciplinary units in English/language arts and social studies/history centered on content area reading and writing. To do so, teachers must locate age-appropriate, historically representative curricular materials and implement discipline-specific writing prompts. To guide elementary teachers' instruction, we select a novel, underused topic: the birth of the Republic of South Sudan. Age-appropriate children's trade books are coupled with diverse informational texts - oral histories, current event news articles, and artwork - to extend the trade books' narratives into the realm of current events. We suggest content area literacy strategies, share anecdotes from their application in the classroom, and recommend engaging, inquiry-based writing prompts that induce students to revisit understandings derived from close readings of the trade books and informational texts. In doing so, all texts and tasks explicitly are connected to different elements of the state and national initiatives in order to help teachers meet the rigorous standards.
Keywords: Children's trade books, South Sudan, historical thinking, content area literacy, informational texts

If countries of the world were members of a family, the Republic of South Sudan would be the baby. It is the world's youngest nation and the newest member of the African Union (54th) and the United Nations (193rd). As the figurative youngster, the Republic of South Sudan receives all sorts of attention. The world watched as Sudanese citizens voted to create an independent Republic of South Sudan, a nation-state autonomous from Sudan. The July 2011 celebration was an epic and triumphant moment, evocative of other countries' day of independence. This patriotic tree of independence has roots grounded in the rubble of a decadeslong civil war; its branches are threatened by the strife associated with nation building. The story of the birth of the Republic of South Sudan is too new to be called history. It lies within the realm of unfolding events.

The story of South Sudan has the potential to engage preadolescent students. While the tale is evolving literally as the seasons change, its origins appear at least a generation ago. Rich historical fiction trade books, like Brothers in Hope: The Story of the Lost Boys of Sudan (Williams \& Christie, 2005) and A Long Walk to Water (Park, 2011), depict the "Lost Boys" of Sudan as they navigate their war-torn country to their location of refuge. Critical reviews indicate their historicity in capturing the essence of the Lost Boys' struggles and successes (Jorgensen \& Rezac, 2013; Pierce, 2006; Reilly, 2008; Rycik \& Rosier, 2009; Sullivan, 2013). 
Various awards-Coretta Scott King Illustrator Honor Book, American Library Association Notable Book Award, and the Jane Addams Children's Book Award - demonstrate their ability to captivate the reader. The events and details within these acclaimed narratives both converge and diverge. When juxtaposed, Brothers in Hope and A Long Walk to Water provide students distinctly different metaphorical maps of the same land.

\section{Literary Convergences and Divergences}

Students quickly notice similarities between Garang Deng, in Brothers in Hope, and Salva Dut, in A Long Walk to Water, even though their paths never cross. They are each unassuming boys when war breaks out, one tending cattle and the other daydreaming in school. With their villages destroyed, Garang and Salva flee. They find tenuous safety first by traveling in larger groups and then upon arriving at an Ethiopian refugee camp. When war erupts in Ethiopia, the refugee camp is dissolved and its occupants are compelled to return to Sudan. Garang and Salva traverse the Gilo River, located in Ethiopia, before they pass through Sudan on their way south to Kenya. In Kenya, they inhabit Kakuma, a refugee camp, until American host families adopt them. Garang and Salva each receive assistance from a White man at opportune times prior to leaving Africa; Michael taught Salva rudimentary English and Tom offered guidance for Garang to locate Kakuma in Kenya. While Garang and Salva had similarly fortuitous trajectories in life, young readers will note important differences.

The narratives center on the preteen Salva Dut and Garang Deng, a child, differing, however, in more than simply age. In A Long Walk to Water, Salva and his Dinka tribe are raided and robbed by the rival Nuers. Salva's uncle is shot and killed. The terror of facing an automatic weapon by day juxtaposes with the horror of being awakened at night to a lion eating Marial, a friend. At the Gilo River crossing, Salva describes how travelers faced drowning, bullets, and crocodiles, the latter two leaving blood red streaks and bodies floating in the river. Violent elements manifest throughout A Long Walk to Water but are largely absent from Brothers in Hope. Garang, the central character of Brothers in Hope, notes no violent details; he was too afraid at the time to commit his experiences to memory and then to paper. Garang, however, recounts the crass yet essential experience of drinking his own urine to combat dehydration. While Salva similarly experienced unquenchable thirst, only Garang confesses to this specific survival step. Students scrutinizing the narratives will likely note that the violent themes within A Long Walk to Water and Garang's unpleasant, desperate efforts to survive in Brothers in Hope did not emerge in both books. Students will likely distinguish also different degrees of leadership and survival. Salva, a preteen, was the leader of over 1,200 boys while Garang led only Chuti, a child younger than him. Garang and all 35 mates in his traveling band made it successfully to Kenya while nearly everyone who attempted to cross the Gilo with Salva was killed.

Simultaneous readings of Brothers in Hope and A Long Walk to Water compel students to compare and contrast key details. Juxtaposition complicates students' thinking as they recognize contested elements and nuanced contours within the historical and literary terrain. It has the potential to facilitate a rigorous, collaborative, multifaceted inquiry, especially if the teacher asks, "Both books are based on actual events, but I wonder which of the books' narratives is more historically representative?" "How would we know?" State and national initiatives create interdisciplinary space for students' involvement in inquiry, civic engagement, and historical analysis and organization of diverse source material (National Governors Association Center for 
Best Practices \& Council of Chief State School Officers [NGA \& CCSSO], 2010; Council of Chief State School Officers [CCSSO], 2012; Partnership for Assessment of Readiness for College and Careers [PARCC], 2012). The subsequent section provides texts and tasks to guide students' scrutiny of unexplored content and creative demonstrations of newly generated understandings. The texts act as a bridge to recent, relevant developments in the region and the tasks serve as the disciplinary-specific literacy instruments needed for exploration.

\section{Integrating Texts and Tasks}

State and national initiatives require close readings of diverse, varied, and interconnected texts in order for students to gain a more comprehensive view of an event, era, or person (CC.RH.6-8.9; PARCC, 2012). Students are to interpret, to integrate, and to evaluate multiple primary and secondary texts of the same event in order to construct complex, nuanced understandings. These newly generated understandings should inform students' disciplinespecific, text-based writing. The subsequent informational texts illustrate refugees' experiences in escape and, for the lucky ones, relocation. Contemporary, emergent events for the new nation of South Sudan are also integrated within the rich informational texts. When grouped, these sources extend the history-based trade books into a contemporary and civic education context, a goal of the C3 framework (CCSSO, 2012). Discipline-specific, text-based tasks facilitate students' close readings.

\section{Refugees' Artistic Representations}

Artwork, like photographs, can engage visual learners of all abilities and can elicit struggling readers' interests in ways text-based primary sources may not. The perspectives constructed and expressed in art are distinct from photographs as the artists' figurative fingerprints are evident. Art enables students to visually interpret and contextualize, which are important elements of visual literacy (Marshall, 2005; Russell-Bowie, 2009).

African refugees' experiences fleeing countries were noted in Sybella Wilkes and Nicola Barber's (2004) book, One Day we had to Run! Refugee Children Tell their Stories in Words and Paintings, a captivating resource. The documentary, Lost Boys of Sudan, incorporated many of the refugees' art (Mylan \& Shenk, 2004). Illustrative examples of such art are also available for download and classroom use at the webpage of the Public Broadcasting System (PBS).

A resourceful teacher could provide various artistic renderings for students to interpret. Students' analysis could initially center on the scene the artist intended to depict. Targeting the seventh standard (CC.RH.6-8.7), the teacher might ask, "If this piece of art was inserted in the book Brothers in Hope and A Long Walk to Water, on which page would it appear? Explain your answer using key details." Students might observe elements from the stories the artist did not include and then (literally) extend the art by drawing beyond its borders to incorporate such elements. Using the sixth standard (CC.RH.6-8.6) as a guide, the teacher could involve students in considering how the painting's title informed their analysis. Titles illuminate elements of the story and guide the audience towards a specific scene. The Walking of the Many, Dinka Man Fighting Buffalo, and My Village in Sudan are representative examples of those found at PBS's webpage. To facilitate scrutiny and contemplation, teachers can separate the art from the titles; assign numbers to the art and letters to the art's titles; and enable students to examine the content of the numbered art and lettered titles in order to determine the proper combination of title and art (CC.RH.6-8.6). 
Students in Molly's classroom responded positively to these novel tasks that rely as much on play as on prior knowledge. Envisioning where an art piece might best fit within a book's narrative provided children numerous choices to consider; upon selection, a text-based justification offered students experience in the types of writing encouraged by contemporary education initiatives (CC.W.6.1). Expanding the art by drawing beyond its original borders enabled students to artistically create and visually demonstrate newly generated understandings; the accompanying text-based rationale gave students the opportunity to intertwine evidence from multiple sources in writing (CC.W.6.9). Examining and combining detached titles with title-less art enabled students to critically evaluate related but decontextualized documents; defending in writing one's combinations satisfied other expectations of state and national initiatives (CC.W.6.8). Each task ostensibly balanced text-based analysis with playful experimentation. Students valued the autonomy and Molly valued her students' written criticality, which derived from close readings of print and visual texts.

\section{Refugees' Oral Histories}

Oral histories are rich with details and provide eyewitness accounts to young learners. Their experiences personalize events that can be dryly or superficially depicted in newspapers. Transcribed oral histories can also be abridged to the students' reading level; teachers can determine the appropriate length, vocabulary complexity, and degree of sensitive content (Bickford \& Rich, 2014; Bolick \& McGlinn, 2004; Wineburg \& Martin, 2009).

God Grew Tired of Us is based largely on John Dau's experience (Quinn \& Walker, 2006). Dau's oral history is available as a book under the same title or in abridged format online (National Geographic, n.d.). John Deng Langbany's oral history was both distinct yet similar to Garang Deng and Salva Dut experiences. Langbany's first person account can captivate listeners with evocative disclosure: "My first memories of my childhood start when I was about five years old in my homeland of Sudan, the day when my parents' house was burned. It was the last day I saw them (PBS, n.d.)." As with countless other transcribed oral histories, Langbany's account is profound, detailed, free for classroom use, and modifiable for graphic content, prose, syntax, and length.

Close readings of the oral histories can facilitate students' recognition of similarities and singularities (Bickford, 2013; Nokes, 2011; Wineburg, Martin, \& Monte-Sano, 2011). Close readings - where students scrutinize the material, considering what was said, how it was said, and what was left unsaid - are foundational to criticality (CC.RH.6-8.5). The close reading could be followed with an activity that assists students' comprehension and inspection of nuanced details. Graphic organizers, like Venn diagrams and concept maps, are effective tools to enable students to systematize their understandings (CC.RH.6-8.1). A Venn provides space for juxtaposition of the experiences of a literary character and an actual survivor. Students reflect on their understandings to appropriately position the convergences and divergences on a Venn. A concept map enables students to thematically organize the experiences and accomplishments of multiple survivors or literary characters. Utilizing either graphic organizer enables students to visually map the relationship between diverse accounts of the same event (CC.RH.6-8.9). Both graphic organizers can be problematic for different reasons. Venn diagrams become cluttered when more than two circles-representing more than two accountsappear. Concept maps provide, at times, too much flexibility allowing a student to rely too heavily on a single account. 
Molly required close readings of two historical fiction books and two oral histories, so a more complex approach was needed. A four-circle Venn diagram-with a single common area in the middle - filled one side of the paper while a concept map filled the other. The Venn compelled students to consider each text individually and identify overarching similarities; the concept map provided students the flexibility to visually diagram areas of distinction and interconnection in a way that best suited their view of the content.

\section{Newspaper Accounts}

Newspaper articles — derived from either print or web-based sources - provide distinct social, geopolitical, and economic angles of events. Newspaper articles from reliable sources complement the poignant oral histories and trade books. With appropriate scaffolding and practice, even young students can determine the credibility of such sources (Baildon \& Baildon, 2012; Bickford \& Rich, 2014; Wineburg et al., 2011). Digital newspaper accounts, especially, provide the teacher an opportunity to modify the length, prose, and syntax of an unwieldy yet relevant article (Wineburg \& Martin, 2009).

Five specific, relevant events extend the trade books' narratives into current events. These included: (1) the vote for South Sudan to separate from Sudan (Cable News Network Wire Staff, 2011); (2) South Sudan's independence day (British Broadcasting Corporation Wire Staff, 2011); (3) South Sudan's recognition by the United Nations (United Nations News Centre Wire Staff, 2011); (4) South Sudan's continued conflict with Sudan over oil and hegemony (Bayoumy \& Martina, 2012); and (5) South Sudan's internal strife and resultant famine in the subsequent year and a half (Jorgic, 2014). Such resources can be used to involve students in detective-like work. Investigative work relies on prior knowledge, analytical thinking, and, at times, teachermade manipulatives. An inventive teacher could randomly number and separate the titles, dates, and (abridged) content of each news article (see Appendix 1-Reorganized and Abridged News Articles). (The news articles were shortened both for manageability for this activity and to elicit students' queries about what was removed.) Once shuffled and placed in an envelope, students scrutinize the various articles' titles, dates, and (abridged) content in an attempt at reassembly (CC.RH.6-8.9). Students, in doing so, analyze the documents for chronological placement; this task compels contextualization, an element of historical thinking not present in simply reading for comprehension (CC.RH.6-8.3). Students begin by sequencing the dates, a simpler task, and move on to pairing titles with their logical accompanying content (CC.RH.6-8.7). Sequencing the articles' titles, dates, and contents potentially evokes queries about the significance of formal recognition by the United Nations (UN), the consequence of conflict with Sudan, and the implications of famine, among other things. Curiosity - fostered by the confusion inherent with this task - can potentially deepen students' interest. A resourceful teacher could provide germane photographs for students integrate into the timeline (CC.RH.6-8.7). The world's press corps captured the events as they unfolded, providing teachers with a myriad of profound images to use in the classroom.

Molly noted the reflection and reconsideration that emerged as her students positioned photographs in the appropriate slot on the timeline. Students viewed their timeline from a different angle and, in doing so, reexamined the accuracy and relevance of the timeline's elements. Such reconsideration, which incorporated reflection and reevaluation, is as important to history as checking one's work is in math. 


\section{Authentic Assessments}

The aforementioned texts and tasks guided students towards a deeper, more nuanced understanding of the region, the turmoil's immediate impact on countless others, and subsequent events. Discipline-specific writing is both central to analysis and routinized over time. The subsequent assessments provide space for more extensive writing where revision is required and synthesis of diverse sources is expected.

\section{Afterword Creation}

When asked to consider the historicity of Brothers in Hope and A Long Walk to Water, Molly's students largely deemed each to be authentic yet incomplete. Through no fault of their own, Brothers in Hope and A Long Walk to Water are products of their respective publication dates (Schwebel, 2011, 2014). They simply lack reference to recent events. They are each in need of a current Afterword.

Students tasked with writing the script to the Afterword meet multiple Common Core Writing Standards for Grade Six (CC.W.6-8.2; CC.W.6-8.4-8; CC.W.6-8.9b; CC.W.6-8.10). Students' grasp on the content in the above sections is foundational for writing the Afterword; their involvement in this task mirrors the inquiry arc (CCSSO, 2012). Through guided inquiry, Molly directed her students to explore the Lost Boys' acclimation to America, the lives of those who could not emigrate, and current humanitarian concerns and geopolitical tensions in the region. International news organizations and humanitarian websites provided the roots for exploration as students read and developed synthesized understandings through writing. Ageappropriate scaffolding, like peer revision and teacher guidance, bolstered students' writing. Complexity, clarity, and adherence to writing conventions were addressed separately and frequently.

Students' writing skills were sharpened when both providing and receiving specific feedback just as their understandings were enhanced when reading peers' final products. The discipline-specific writing and age-appropriate scaffolding provided students the space and support to interpret and integrate diverse informational texts as they construct an Afterword to either Brothers in Hope or A Long Walk to Water. Students' historical thinking and newly generated understandings were visible in such text-based writing.

\section{Inquiry of African Countries}

Africans, at times, are unnecessarily grouped together based on their geographical location on the continent of Africa. They can and should be seen as citizens of a specific country and members of a specific culture, not simply occupants of the African continent. The nuances and significant distinctions separating African countries are vast, as they are with all countries that share a continent.

Students can benefit from exploring relevant aspects of a single country's history, geography, culture and society, and germane current events. Molly tasked her students with researching many elements within each of the aforementioned aspects. Such inquiry enables students to explore and synthesize content derived from diverse informational texts. The expository texts are age-appropriate, current resources that target in, no particular order, Mali (Blauer \& Laure, 2008), Tanzania (Heale \& Wong, 2009), Mozambique (King, 2007a), Rwanda (King, 2007b), Nigeria (Levy, 2004), Sudan (Levy \& Latif, 2007), Liberia (Levy \& Spilling, 2009), South Africa (Rosmarin \& Rissik, 2014), Morocco (Seward, 2006), and Jordan (South, 2007). Individual inquiry - centered on a single country's history, geography, culture and society, and current events - is not novel. The task, however, compels students to view Brothers 
Social Studies Research and Practice

www.socstrp.org

in Hope, A Long Walk to Water, and those who experienced South Sudan's birth in a broader, more nuanced context. 


\section{References}

Baildon, M. \& Baildon, R. (2012). Evaluating online sources: Helping students determine trustworthiness, readability, and usefulness. Social Studies and the Young Learner, 24(4), 11-14.

Blauer, E. \& Laure, J. (2008). Mali: Cultures of the world. New York, NY: Cavendish Square Publishing.

Bickford, J. (2013). Initiating historical thinking in elementary schools. Social Studies Research and Practice, 8(3), 60-77.

Bickford, J. \& Rich, C. (2014). Historical thinking and Common Core: Facilitating adolescents' scrutiny of the credibility of slave narratives. The Councilor: A Journal of the Social Studies, 75(1), 1-14.

Bolick, M. \& McGlinn, M. (2004). Harriet Jacobs: Using online slave narratives in the classroom. Social Education 68(3), 198-202.

Council of Chief State School Officers (2012). Vision for the college, career, and civic life (C3) framework for inquiry in social studies state standards. Washington, DC: Department of Education.

Heale, J. \& Wong, W. (2009). Tanzania: Cultures of the world. New York, NY: Cavendish Square Publishing.

Jorgensen, A. \& Rezac, T. (2013). Novel study in the ELL classroom: A rich library collaboration. School Library Monthly, 30(3), 38-39.

King, D. (2007a). Mozambique: Cultures of the world. New York, NY: Cavendish Square Publishing.

King, D. (2007b). Rwanda: Cultures of the world. New York, NY: Cavendish Square Publishing.

Levy, P. (2004). Nigeria: Cultures of the world. New York, NY: Cavendish Square Publishing.

Levy, P. \& Latif, Z. (2007). Sudan: Cultures of the world. New York, NY: Cavendish Square Publishing.

Levy, P. \& Spilling, M. (2009). Liberia: Cultures of the world. New York, NY: Cavendish Square Publishing.

Marshall, J. (2005). Connecting art, learning, and creativity: A case for curriculum integration. Studies in Art Education, 46(3), 227-241.

National Governors Association Center for Best Practices \& Council of Chief State School Officers (2010). Common Core state standards for English/language arts and literacy in history/social studies, science, and technical subjects. Washington, DC: Department of Education.

Nokes, J. (2011). Recognizing and addressing the barriers to adolescents' "reading like historians". The History Teacher, 44(3), 379-404.

Park, L. (2011). A long walk to water: Based on a true story. New York, NY: Houghton Mifflin Harcourt.

Partnership for Assessment of Readiness for College and Careers (2012). PARCC model content frameworks: English language arts/literacy, grades 3-11, version 2.0. Washington, DC: Department of Education.

Pierce, J. (2008). Once and future Classics: New releases complement old favorites at ALA Exhibits. American Libraries, 39(7), 80-81.

Reilly, M. (2008). Finding the right words: Art conversations and poetry. Language Arts, 86(2), 99-107. 
Rosmarin, I. \& Rissik, D. (2014). South Africa: Cultures of the world. New York, NY: Cavendish Square Publishing.

Rycik, M. \& Rosier, B. (2009). The return of historical fiction. The Reading Teacher, 63(2), 163166.

Schwebel, S. (2011). Child-sized history: Fictions of the past in U.S. classrooms. Nashville, TN: Vanderbilt University Press.

Schwebel, S. (2014). Historical fiction, Common Core, and disciplinary habits of mind. Social Education, 78(1), 20-24.

Seward, P. (2006). Morocco: Cultures of the world. New York, NY: Cavendish Square Publishing.

South, C. (2007). Jordan: Cultures of the world. New York, NY: Cavendish Square Publishing.

Sullivan, C. (2013). Disturbing (or not?) young adult fiction. The Horn Book Magazine, September/October, 51-55

Wilkes, S. \& Barber, N. (2004). One day we had to run! Refugee children tell their stories in words and paintings. London, England: Evans Brothers Ltd.

Williams, M. \& Christie, R. (2005). Brothers in hope: The story of the Lost Boys of Sudan. Lee \& Low Books.

Wineburg, S. \& Martin, D. (2009). Tampering with history: Adapting primary sources for struggling readers. Social Education, 73(5), 212-216.

Wineburg, S., Martin, D., \& Monte-Sano, C. (2011). Reading like a historian: Teaching literacy in middle and high school history classrooms. New York, NY: Teachers College Press.

\section{Web-based References}

Bayoumy, Y. \& Martina, M. (2012, April 24). South Sudan accuses Khartoum of declaring war. The Chicago Tribune. Retrieved from http://articles.chicagotribune.com/2012-0424/news/sns-rt-us-sudan-south-conflictbre83n13z-20120424_1_south-sudan-presidentsalva-kiir-civil-war-foes

British Broadcasting Corporation Wire Staff (2011, July 9). South Sudan's flag raised at independence ceremony. British Broadcasting Corporation. Retrieved from http://www.bbc.com/news/world-africa-14092375

Cable News Network Wire Staff (2011, January 30). Complete results show 99\% vote to split in Southern Sudan. CNN World. Retrieved from http://www.cnn.com/2011/WORLD/africa/01/22/sudan.referendum.results/

Jorgic, D. (2014, August 14). South Sudan leaders show little appetite for peace deal: U.N. The Chicago Tribune. Retrieved from http://www.chicagotribune.com/news/sns-rt-ussouthsudan-unrest-un-20140814-story.html

Mylan, M. \& Shenk, J. (28 September 2004). Lost Boys of Sudan: Documentaries with a point of view. United States: Public Broadcasting System. Retrieved from http://www.pbs.org/pov/lostboysofsudan/

National Geographic (n.d.). Sudan's Lost Boys. Retrieved from http://ngm.nationalgeographic.com/ngm/0701/voices/voices.html

Public Broadcasting System (n.d.). Lost Boys of Sudan. Retrieved from http://www.pbs.org/pov/lostboysofsudan/

Quinn, C. (Producer, Writer, \& Director) \& Walker, T. (Director) (2006). God Grew Tired of Us. United States: National Geographic. 
Russell-Bowie, D. (2009). Syntegration or disintegration? Models of integrating the arts across the primary curriculum. International Journal of Education \& the Arts, 10(28). Retrieved from October 13, 2014 from http://www.ijea.org/v10n28/

United Nations News Centre Wire Staff (2011, July 14). UN Welcomes South Sudan as 193rd Member State. UN News Centre. Retrieved from

http://www.un.org/apps/news/story.asp?NewsID=39034\&Cr=South+Sudan\&Cr1=\#.VCx GICldVQY 


\section{Appendix 1 - Reorganized and Abridged News Articles}

\section{Title: Complete results show 99\% vote to split in Southern Sudan}

Date: January 30, 2011

Content: Nearly 99\% of Southern Sudanese voted to split from the north, organizers reported Sunday, marking the first complete preliminary results. With $100 \%$ of votes counted, an overwhelming 98.83\% voted to split, the Southern Sudan Referendum Commission said on its website. Sudan's north and south have been at war for two decades in a conflict that killed 2 million people. The referendum on whether to declare independence from the government based in the north is part of a 2005 peace agreement that helped end the conflict. The war pitted a government dominated by Arab Muslims in northern Sudan against black Christians or animists in the south. A majority of Sudan's oil reserves are in the south, another flashpoint in the war.

Several million voters cast ballots, including expatriates in the United States and seven other countries. The south would become a new nation in July if the vote is validated and no other obstacles emerge. ...

Title: South Sudan's flag raised at independence ceremony

Date: July 9, 2011

Content: Salva Kiir signed the constitution and took his oath of office in front of the jubilant crowds, becoming president of the world's newest nation. Sudan's President Omar al-Bashir and UN chief Ban Ki-moon were among dignitaries watching the events. Sudan earlier became the first state to officially recognise its new neighbour. The world's newest nation was born at midnight local South Sudanese time, the climax of a process made possible by the 2005 peace deal that ended a long civil war. The south's independence follows decades of conflict with the north in which some 1.5 million people died. ... South Sudan is rich in oil, but is one of the least developed countries in the world, where one in seven children dies before the age of five. Correspondents say keeping both the north and the south stable long after the celebratory parties have ended will be a challenge. ...

Title: UN welcomes South Sudan as 193rd Member State

Date: July 14, 2011

Content: The General Assembly today admitted the Republic of South Sudan as the 193rd member of the United Nations, welcoming the newly independent country to the community of nations. South Sudan's independence from the rest of Sudan is the result of the January 2011 referendum held under the terms of the 2005 Comprehensive Peace Agreement (CPA) that ended the decades-long civil war between the North and the South. "At this moment... in this place... the world gathers to say in one voice: Welcome, South Sudan. Welcome to the 
community of nations," Secretary-General Ban Ki-moon said after the Assembly adopted a resolution, by acclamation, to admit Africa's newest country. Mr. Ban, who was among the UN dignitaries who attended the independence ceremony in South Sudan's capital, Juba, last Saturday, pledged the world body's assistance as the country shapes its future. ...

Title: South Sudan accuses Khartoum of declaring war

Date: April 24, 2012

Content: South Sudan accused Sudan on Tuesday of mounting bombing raids on the newly independent country's oil-producing border region and President Salva Kiir said the latest hostilities amounted to a declaration of a war by his northern neighbor. Weeks of cross-border fighting between the former civil war foes have threatened to escalate into a full blown conflict in a region that holds one of Africa's most significant oil reserves. Although both Sudan, ruled by President Omar al-Bashir since 1989, and South Sudan, which became independent last July under a peace deal with Khartoum, can ill-afford a protracted war, both countries have fuelled tensions with bellicose rhetoric. The United States, China and Britain urged both sides to return to the negotiating table. "We strongly condemn Sudan's military incursion into South Sudan. Sudan must immediately halt the aerial and artillery bombardment in South Sudan by the Sudan armed forces," White House spokesman Jay Carney said. Sudan's foreign minister said he was ready to discuss security issues with the South. ...

Title: South Sudan leaders show little appetite for peace deal: U.N.

Date: August 14, 2014

Content: President Salva Kiir and rebel chief Riek Machar show little interest in making a deal to end months of fighting that has brought the nation to the brink of "man-made" famine, U.N. Security Council envoys said during a visit to East Africa. Clashes in December between soldiers loyal to Kiir and supporters of his former deputy Machar plunged the oil-producing country back into conflict, less than three years after its hard-won independence from former civil war foe Sudan. Kiir and Machar signed a ceasefire in May ... and agreed to form an interim government within 60 days but that deadline expired on Aug 10 as talks stalled. Diplomats say both sides violated the truce, though negotiations continue. ... At least 10,000 people have been killed and more than 1.1 million displaced during nearly eight months of onoff fighting in South Sudan. Samantha Power [the U.S. ambassador to the United Nations] said 50,000 children under five were at risk of dying of malnutrition in the coming months. Aid agencies say South Sudan is hurtling toward the worst famine in East Africa since the mid1980s, when malnutrition swept through the region and killed over a million people. ... 


\section{Author Bios}

John H. Bickford III is a former Mid-Prairie Middle School (Kalona, IA) social studies teacher and current Assistant Professor of Elementary and Middle Level Education at Eastern Illinois University (Charleston, IL). His research explores the texts and tasks that facilitate elementary and middle level students' historical thinking. Email: jbickford@eiu.edu.

Molly Sigler Bickford is a 6th grade English/language arts teacher at Unity Junior High School (Tolono, IL). She is indebted to Mrs. Kathy Wickline for suggesting quality literature and providing classroom support. E-mail: bickfordm@unity.k12.il.us. 